\title{
Spatio-temporal variation in the macrobenthos of Paradip port, east coast of India
}

\author{
Noyel, V. ${ }^{1,2}$ and Dattesh V. Desai ${ }^{1, *}$ \\ ${ }^{1}$ CSIR-National Institute of Oceanography, Dona Paula, Goa 403 004, India \\ ${ }^{2}$ School of Earth, Ocean and Atmospheric Sciences, Goa University, Goa 403 206, India
}

\begin{abstract}
The spatio-temporal variation in the abundance and community structure of macrobenthic invertebrates, which are useful ecological indicators, was assessed along with associated environmental settings and sediment characteristics in Paradip port, Odisha along the east coast of India. The Paradip port is a coastal port directly connected to the Bay of Bengal and is influenced by tropical monsoons. The maximum diversity and abundance of macroinvertebrates was reported during monsoon season, whereas it was minimum during post-monsoon and pre-monsoon and attributed to higher organic carbon in the sediments. The sediment characteristics (sediment composition and total organic carbon) were the major factors influencing the abundance and community composition of benthic organisms. Silty-sand was dominant throughout the port environment. The polychaetes were the dominant macrobenthos organisms followed by Pantopoda and Crustaceans. Organically rich and sandy-silt sediments have led to the dominance of pollution indicator taxa such as Tharyx sp., Prionospio sp., Cossura sp., Magelona sp. and Mediomastus sp. The multivariate index of trophic state indicated good water quality in near bottom water; however, high organic carbon load in the sediments could have resulted in a stressed environment. This study will serve as a baseline for future studies on the diversity of macrobenthic invertebrates and benthic ecology of the monsoon influenced coastal habitats, especially in a busy port subjected to rigorous physical and anthropogenic stress.
\end{abstract}

Keywords: Coastal port, macrobenthos, polychaetes, spatio-temporal variation, species diversity.

THE benthic fauna are an important link in the food web and are useful both ecologically and economically. Benthic organisms play a major role in the marine community with their involvement in mineralization, sediment mixing, oxygen flux, nutrient cycling and in the recovery of organic matter ${ }^{1}$. They are used as bio-indicators for pollution monitoring studies owing to their short life cycles and limited mobility, tertiary-level feeders and food for several bottom-dwelling higher invertebrates and fishes ${ }^{2}$. Polychaetes are the most abundant and dominant

*For correspondence. (e-mail: ddattesh@nio.org) groups in the benthic community which contribute to $80 \%$ of total macrobenthic population. They are being used for biomonitoring organic pollution and to check the quality of the marine environment ${ }^{3}$.

Ports are considered as the lifeline of a country's economic development and port areas are one of the highly disturbed coastal habitats due to heavy traffic owing to shipping and also human activities ${ }^{4}$. Since they are often located in the coastal environments, port areas are subjected to various forms of anthropogenic stressors such as untreated sewage or municipal run-off, terrestrial run-off during monsoon, and port-related activities such as dredging, oil spill, petroleum effluents, out-fall of a variety of cargo handled by the port, etc. ${ }^{5}$. Port waters are often characterized by low dissolved oxygen and the presence of pollutants in the sediments and water ${ }^{5-8}$. As harbour areas have empty niches, they are prone to marine bioinvasion especially due to discharge of ship ballast water ${ }^{9,10}$, as the empty niches are formed due to instability of the equilibrium between the origination and extinction of the benthic community ${ }^{11}$. Bioinvasion is of global concern due to its adverse effect on biodiversity and ecosystem functioing ${ }^{12}$.

The distribution and community of macrobenthic organisms depend on the interaction between the physical, chemical and biological variables in both water column and sediments. So to study the diversity and abundance of macrobenthic organisms, it is important to assess the factors affecting the benthic community mainly sediment characteristics such as texture, organic content and food availability. The present study was carried out to observe the spatio-temporal variation in the macrobenthic diversity and abundance, and to examine the impact of sediment characteristics and environmental parameters on macrobenthos in a dynamic port environment situated along the east coast of India.

\section{Material and methods}

\section{Study area}

Sampling in Paradip port was carried out during August 2014 (monsoon I-MI), December 2014 (post-monsoon PM), May 2015 (pre-monsoon - Pre-M) and August 2015 (monsoon II - M II) representing different seasons. This 
is a major port along the east coast of India in Odisha $\left(20^{\circ} 15^{\prime} \mathrm{N}, 86^{\circ} 40^{\prime} \mathrm{E}\right.$; Figure 1). The port is influenced by the south-west monsoon (June-September) and receives $75-80 \%$ of rainfall during these months, and remaining during the northeast monsoon (October-December). On the east coast, this port manages a large amount of trade of the country. Even though this is a natural deep water port, artificial bunds (breakwaters) were built to reduce the severe wave intensity in the port; thus it resembles an artificial lagoon. The breakwaters are: (1) south breakwater with a length of $1217 \mathrm{~m}$ and (2) north breakwater with a length of $538 \mathrm{~m}$. It is a major port that handles various cargo such as crude oil, petroleum, oil and lubricants (POL), iron ore, thermal coal, chrome ore, coking coal, manganese and other ores, fertilizer raw materials and containers, etc. The samples were collected from 22 stations in accordance to berths, and Table 1 provides their details.

\section{Sampling and analysis}

The near-bottom sea-water samples were collected (in triplicate) for the analysis of chlorophyll $a$, salinity, dissolved oxygen (DO), temperature and nutrients using

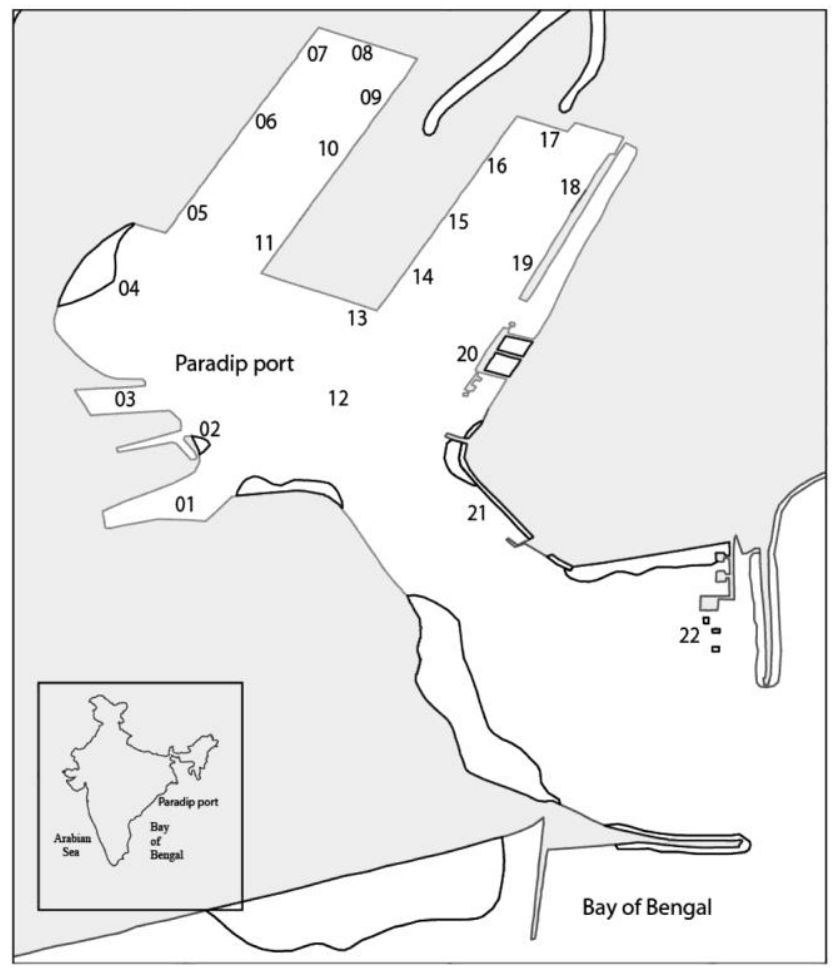

Figure 1. Map showing the sampling stations in Paradip port. S01, Boat Basin; S02, Slip Way; S03, Deep Sea Trawler Berth; S04, Area Adjacent to Fertilizer Berths; S05, Fertilizer Berth-I; S06, Fertilizer Berth-II; S07, Multipurpose Berth; S08, North Quay-II; S09, Central Quay-III; S10, Central Quay-II; S11, Central Quay-I; S12, Turning Circle; S13, South Quay; S14, East Quay-I; S15, East Quay-II; S16, East Quay-III; S17, North Quay-I; S18, Coal Berth-Il S19, Coal BerthII; S20, Iron Ore Berth; S21, Stone Pitching Side and S22, Oil Berth.
Niskin water sampler and analysed using standard protocols ${ }^{13}$. Nutrients such as nitrate $\left(\mathrm{NO}_{3}\right)$, phosphate $\left(\mathrm{PO}_{4}\right)$, nitrite $\left(\mathrm{NO}_{2}\right)$, ammonium $\left(\mathrm{NH}_{4}\right)$ and silicate $\left(\mathrm{SiO}_{4}\right)$ were analysed using SKALAR SANplus analyzer. Sediment samples were collected in triplicate from an average depth of $13-16 \mathrm{~m}$ using a van Veen grab $\left(0.04 \mathrm{~m}^{2}\right)$. The sediment samples were washed separately through a $500 \mu \mathrm{m}$ nylon mesh in the field and then preserved in $10 \%$ formaldehyde in sea water containing rose Bengal stain before transferring them in a plastic container.

Laboratory analysis involved the sorting of macrobenthic organisms from the sediment samples that were sieved through a $500 \mu \mathrm{m}$ metal sieve. The macrobenthic fauna collected were preserved in plastic vials containing $10 \%$ formaldehyde solution for further microscopic analysis. Polychaetes (Phylum-Annelida) were identified to the highest taxonomic level (genus or species), with the help of available identification keys ${ }^{14-16}$ and other macrobenthos were identified up to group, family or genus levels. Numerical abundance of each species was expressed as number per square metre. Biomass was determined using wet weight method and expressed as milligram per metre square $^{17}$. Total carbon (TC) and inorganic carbon (IC), and percentage composition of sediments (sand, silt and clay) that are expressed as the percentage of sediment dry weight were determined using CHNS Analyser (Vario MICRO Select, Germany) and pipette analysis respectively $^{18,19}$. The total organic carbon (TOC) content was obtained by the difference between TC and IC $(\mathrm{TOC}=\mathrm{TC}-\mathrm{IC})^{20}$.

Number of individuals or specimens $(N)$, number of species $(S)$, total abundance $(A)$, Margalef species richness $(d)$, Pielou's eveness $\left(J^{\prime}\right)$ and Shannon index $\left(H^{\prime}\right)$ using $\log 2$ scale were used to determine the environmental and ecological assessment of macrobenthic organisms in each station. PRIMER-v5 was used to determine the similarity of species diversity in macrobenthic polychaetes by Bay-Curtis similarity index (ref. 21). Canonical correspondence analysis (CCA) and redundancy analysis were performed to evaluate the relationship between environmental variables and different groups of macrobenthos. The multivariate index of trophic state (TRIX) method was used to evaluate the trophic status of Paradip port ${ }^{22}$. This allows us to determine the water quality and also the relationship between trophic status of near bottom water and sediments.

TRIX was calculated as

$$
\text { TRIX }=\frac{\left(\log _{10}\left(\operatorname{chl} a \times \mathrm{a} \% \mathrm{O}_{2} \times \mathrm{DIN} \times \mathrm{DIP}\right)+k\right)}{m, \text { of DO saturation }\left(\text { abs }\left|100-\% \mathrm{O}_{2}\right|=\% \mathrm{O}_{2}\right)},
$$

where chl $a$ is in $\mathrm{mg} \mathrm{m}^{-3}, \mathrm{a} \% \mathrm{O}_{2}$ is absolute value of the percentage of DO saturation (abs $\mid 100-\% \quad \mathrm{O}_{2}=\% \mathrm{O}_{2}$ ), DIN is dissolved inorganic nitrogen including $\mathrm{NO}_{3}, \mathrm{NO}_{2}$, 
Table 1. Paradip port stations and their locations.

\begin{tabular}{rlrl}
\hline Station no. & \multicolumn{1}{c}{ Station } & Latitude & Longitude \\
\hline 1 & Boat Basin & $20^{\circ} 16^{\prime} 07.6^{\prime \prime} \mathrm{N}$ & $86^{\circ} 40^{\prime} 03.1^{\prime \prime} \mathrm{E}$ \\
2 & Slip Way & $20^{\circ} 16^{\prime} 12.1^{\prime \prime} \mathrm{N}$ & $86^{\circ} 40^{\prime} 07.4^{\prime \prime} \mathrm{E}$ \\
3 & Deep Sea Trawler Berth & $20^{\circ} 16^{\prime} 18.3^{\prime \prime} \mathrm{N}$ & $86^{\circ} 40^{\prime} 02.4^{\prime \prime} \mathrm{E}$ \\
4 & Area Adjacent to Fertilizer Berths & $20^{\circ} 16^{\prime} 27.8^{\prime \prime} \mathrm{N}$ & $86^{\circ} 40^{\prime} 02.9^{\prime \prime} \mathrm{E}$ \\
5 & Fertilizer Berth-I & $20^{\circ} 16^{\prime} 38.1^{\prime \prime} \mathrm{N}$ & $86^{\circ} 40^{\prime} 06.2^{\prime \prime} \mathrm{E}$ \\
6 & Fertilizer Berth-II & $20^{\circ} 16^{\prime} 45.3^{\prime \prime} \mathrm{N}$ & $86^{\circ} 40^{\prime} 11.2^{\prime \prime} \mathrm{E}$ \\
7 & Multipurpose Berth & $20^{\circ} 16^{\prime} 52.7^{\prime \prime} \mathrm{N}$ & $86^{\circ} 40^{\prime} 14.8^{\prime \prime} \mathrm{E}$ \\
8 & North Quay-II & $20^{\circ} 16^{\prime} 54.0^{\prime \prime} \mathrm{N}$ & $86^{\circ} 40^{\prime} 19.4^{\prime \prime} \mathrm{E}$ \\
9 & Central Quay-III & $20^{\circ} 16^{\prime} 50.2^{\prime \prime} \mathrm{N}$ & $86^{\circ} 40^{\prime} 19.1^{\prime \prime} \mathrm{E}$ \\
10 & Central Quay-II & $20^{\circ} 16^{\prime} 43.2^{\prime \prime} \mathrm{N}$ & $86^{\circ} 40^{\prime} 15.5^{\prime \prime} \mathrm{E}$ \\
11 & Central Quay-I & $20^{\circ} 16^{\prime} 35.3^{\prime \prime} \mathrm{N}$ & $86^{\prime \prime} 40^{\prime} 11.6^{\prime \prime} \mathrm{E}$ \\
12 & Turning Circle & $20^{\circ} 16^{\prime} 15.2^{\prime \prime} \mathrm{N}$ & $86^{\circ} 40^{\prime} 15.5^{\prime \prime} \mathrm{E}$ \\
13 & South Quay & $20^{\circ} 16^{\prime} 27.3^{\prime \prime} \mathrm{N}$ & $86^{\circ} 40^{\prime} 14.2^{\prime \prime} \mathrm{E}$ \\
14 & East Quay-I & $20^{\circ} 16^{\prime} 30.5^{\prime \prime} \mathrm{N}$ & $86^{\circ} 40^{\prime} 22.5^{\prime \prime} \mathrm{E}$ \\
15 & East Quay-II & $20^{\circ} 16^{\prime} 37.9^{\prime \prime} \mathrm{N}$ & $86^{\circ} 40^{\prime} 26.3^{\prime \prime} \mathrm{E}$ \\
16 & East Quay-III & $20^{\circ} 16^{\prime} 46.7^{\prime \prime} \mathrm{N}$ & $86^{\circ} 40^{\prime} 29.7^{\prime \prime} \mathrm{E}$ \\
17 & North Quay-I & $20^{\circ} 16^{\prime} 46.1^{\prime \prime} \mathrm{N}$ & $86^{\circ} 40^{\prime} 35.6^{\prime \prime} \mathrm{E}$ \\
18 & Coal Berth-I & $20^{\circ} 16^{\prime} 38.7^{\prime \prime} \mathrm{N}$ & $86^{\circ} 40^{\prime} 34.9^{\prime \prime} \mathrm{E}$ \\
19 & Coal Berth-II & $20^{\prime \prime} 16^{\prime} 30.3^{\prime \prime} \mathrm{N}$ & $86^{\circ} 40^{\prime} 29.0^{\prime \prime} \mathrm{E}$ \\
20 & Iron Ore Berth & $20^{\circ} 16^{\prime} 23.4^{\prime \prime} \mathrm{N}$ & $86^{\circ} 40^{\prime} 25.5^{\prime \prime} \mathrm{E}$ \\
21 & Stone Pitching Side & $20^{\circ} 16^{\prime} 08.8^{\prime \prime} \mathrm{N}$ & $86^{\circ} 40^{\prime} 30.0^{\prime \prime} \mathrm{E}$ \\
22 & Oil Berth & $20^{\circ} 15^{\prime} 52.6^{\prime \prime} \mathrm{N}$ & $86^{\circ} 40^{\prime} 43.1^{\prime \prime} \mathrm{E}$ \\
\hline
\end{tabular}
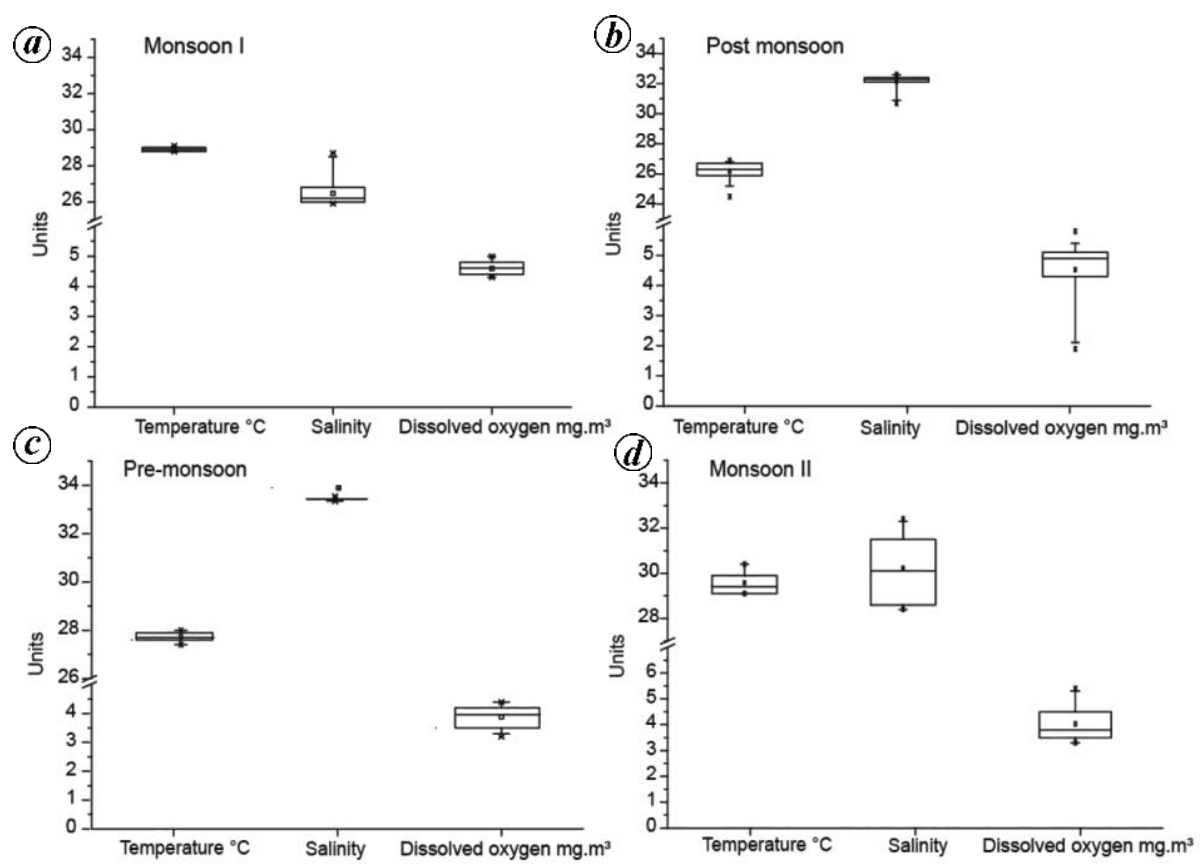

Figure $2 \boldsymbol{a}$-d . Seasonal variations in the bottom-water parameters, temperature $\left({ }^{\circ} \mathrm{C}\right)$, salinity and dissolved oxygen $\left(\mathrm{mg} \mathrm{m}^{3}\right)$ at Paradip port.

$\mathrm{NH}_{4}$ in $\mathrm{mg} \mathrm{m}^{-3}$, DIP is dissolved inorganic $\mathrm{PO}_{4}$ in $\mathrm{mg} \mathrm{m}^{-3}$, constants $\mathrm{k}-3.5$ and $\mathrm{m}-0.8$ are scale values.

\section{Results}

\section{Environmental parameters}

Table 2 and Figure 2 show the variations in near-bottom environmental parameters such as temperature, salinity and dissolved oxygen. The near-bottom sea-water temperature during different seasons ranged between $26.2^{\circ} \pm 0.6^{\circ}$ and $29.7^{\circ} \pm 0.45^{\circ} \mathrm{C}$ (Table 2 and Figure $2 a-d)$.

The salinity of near-bottom water varied with seasons; it was low (26.5 \pm 0.7 and 30.2 \pm 1.4 during M I and M II respectively) during monsoon compared to non-monsoon season $(32.1 \pm 0.5$ and $33.9 \pm 0.04$ during PM and Pre-M respectively; Table 2 and Figure $2 a-d$ ). The near-bottom 
Table 2. Variations in temperature, salinity and dissolved oxygen in near bottom water at Paradip port at different stations during different seasons

\begin{tabular}{|c|c|c|c|c|c|c|c|c|c|c|c|c|}
\hline \multirow[b]{2}{*}{ Station } & \multicolumn{4}{|c|}{ Temperature $\left({ }^{\circ} \mathrm{C}\right)$} & \multicolumn{4}{|c|}{ Salinity } & \multicolumn{4}{|c|}{ Dissolved oxygen $\left(\mathrm{mg} \mathrm{l}^{-1}\right)$} \\
\hline & M I & PM & Pre-M & M II & M I & PM & Pre-M & M II & M I & PM & Pre-M & M II \\
\hline 1 & 28.9 & 26.0 & 27.9 & 30.4 & 25.9 & 30.7 & 33.8 & 28.4 & 5.0 & 5.0 & 4.4 & 5.2 \\
\hline 2 & 28.9 & 26.1 & 27.7 & 30.4 & 26.0 & 30.9 & 33.8 & 28.6 & 5.0 & 3.7 & 4.4 & 5.3 \\
\hline 3 & 28.9 & 26.1 & 27.8 & 30.2 & 26.0 & 31.2 & 33.8 & 28.4 & 4.8 & 4.3 & 4.4 & 5.4 \\
\hline 4 & 28.9 & 25.2 & 27.4 & 29.2 & 26.9 & 32.4 & 33.9 & 29.8 & 4.6 & 4.6 & 4.2 & 4.0 \\
\hline 5 & 28.9 & 24.5 & 27.6 & 29.1 & 26.8 & 32.4 & 33.9 & 30.1 & 4.4 & 4.0 & 3.5 & 3.8 \\
\hline 6 & 29.0 & 26.4 & 27.8 & 29.1 & 26.0 & 32.5 & 33.9 & 30.6 & 4.3 & 1.9 & 4.2 & 3.6 \\
\hline 7 & 28.8 & 26.4 & 27.8 & 29.4 & 26.1 & 32.3 & 33.9 & 30.1 & 4.4 & 5.2 & 4.2 & 3.6 \\
\hline 8 & 28.9 & 26.1 & 27.9 & 29.4 & 26.0 & 32.1 & 34.0 & 29.3 & 4.6 & 5.3 & 4.3 & 3.7 \\
\hline 9 & 28.9 & 26.2 & 27.9 & 29.4 & 26.0 & 32.3 & 33.9 & 29.7 & 4.4 & 5.1 & 4.2 & 3.9 \\
\hline 10 & 28.8 & 26.6 & 27.7 & 29.1 & 26.0 & 32.4 & 33.9 & 32.4 & 4.4 & 2.1 & 3.5 & 3.3 \\
\hline 11 & 28.8 & 25.9 & 27.6 & 29.1 & 26.8 & 32.4 & 33.9 & 32.1 & 4.7 & 4.4 & 3.4 & 3.4 \\
\hline 12 & 29.0 & 25.4 & 27.6 & 29.6 & 28.7 & 32.6 & 33.9 & 28.4 & 4.9 & 5.8 & 4.0 & 4.3 \\
\hline 13 & 28.8 & 25.8 & 27.4 & 29.1 & 28.5 & 32.6 & 33.9 & 32.3 & 4.8 & 3.4 & 4.2 & 3.8 \\
\hline 14 & 28.8 & 25.5 & 27.9 & 29.1 & 26.9 & 32.2 & 33.9 & 32.2 & 4.6 & 4.4 & 3.9 & 3.3 \\
\hline 15 & 29.0 & 26.7 & 28.0 & 29.4 & 26.4 & 32.5 & 33.8 & 31.4 & 4.3 & 4.8 & 3.9 & 3.4 \\
\hline 16 & 29.0 & 26.8 & 27.7 & 29.6 & 26.3 & 32.3 & 33.9 & 31.6 & 4.4 & 4.9 & 3.2 & 3.3 \\
\hline 17 & 29.1 & 26.7 & 28.0 & 29.4 & 26.4 & 32.3 & 33.9 & 31.5 & 4.5 & 4.8 & 3.6 & 3.5 \\
\hline 18 & 28.8 & 26.7 & 27.7 & 29.6 & 26.1 & 32.1 & 33.9 & 31.4 & 4.6 & 5.1 & 3.8 & 3.5 \\
\hline 19 & 28.8 & 26.9 & 27.6 & 30.3 & 26.0 & 32.6 & 33.9 & 29.9 & 4.9 & 5.1 & 3.8 & 4.8 \\
\hline 20 & 28.8 & 26.7 & 27.9 & 29.9 & 26.0 & 31.9 & 33.9 & 28.6 & 4.3 & 5.4 & 3.4 & 4.2 \\
\hline 21 & 28.9 & 26.6 & 27.7 & 29.9 & 26.3 & 32.1 & 33.9 & 29.7 & 4.6 & 5.1 & 3.6 & 4.5 \\
\hline 22 & 29.0 & 26.3 & 27.6 & 29.9 & 26.2 & 32.4 & 33.9 & 28.4 & 4.5 & 5.0 & 3.3 & 4.8 \\
\hline Minimum & 28.8 & 24.5 & 27.4 & 29.1 & 25.9 & 30.7 & 33.8 & 28.4 & 4.3 & 1.9 & 3.2 & 3.3 \\
\hline Maximum & 29.1 & 26.9 & 28.0 & 30.4 & 28.7 & 32.6 & 34.0 & 32.4 & 5.0 & 5.8 & 4.4 & 5.4 \\
\hline Mean & 28.9 & 26.2 & 27.7 & 29.6 & 26.5 & 32.1 & 33.9 & 30.2 & 4.6 & 4.5 & 3.9 & 4.0 \\
\hline SD & 0.09 & 0.60 & 0.17 & 0.44 & 0.76 & 0.52 & 0.04 & 1.43 & 0.22 & 0.99 & 0.39 & 0.68 \\
\hline
\end{tabular}

M I, Monsoon I; Pre-M, Pre-monsoon; PM, Post-monsoon and M II, Monsoon II.

DO ranged from $3.9 \pm 0.3$ to $4.5 \pm 0.9 \mathrm{mg} \mathrm{l}^{-1}$ during the study (Table 2 and Figure $2 a-d$ ). The concentration of bottom-water nutrients varied with the seasons and stations (Supplementary Figure 1). The tidal range at Paradip port is from 0.2 to $3.5 \mathrm{~m}$ and the maximum wave height is $5.3 \mathrm{~m}$. TRIX analysed for the bottom water during the study was $1.8 \pm 0.8$, indicating high state of water quality with low eutrophication. TRIX scores ranged from 0.07 to 3.39 during all the seasons indicating healthy bottom-water conditions.

The sediment texture was composed of sand, silt and clay and it varied spatio-temporally within the port (Figure $3 a-d)$. In general, silt was the dominant component $(59.0 \% \pm 26.8 \%)$, followed by sand $(37.3 \% \pm 26.3 \%)$ and clay $(2.8 \% \pm 9.5 \%)$ during all seasons in most of the stations. The sand content was comparatively higher during Pre-M. The silt content showed wide fluctuation and ranged from $5.3 \%$ to $94.6 \%$ (Figure $3 \mathrm{~b}$ ). The percentage of clay was minimum when compared to sand and silt and it ranged from $0.3 \%$ to $3.8 \%$ (Figure $3 a-d$ ). Overall, the sediment texture at Paradip port was dominated by silt, followed by silty-sand and sandy-silt, and few stations were dominated by sand (Figure $3 e$ ). TOC in the sediments ranged from $0.5 \%$ at S06 to $31.6 \%$ at S04. During M I (Figure $4 a-d$ ), the average TOC was maximum
$(5.6 \% \pm 7.4 \%)$ while it was minimum $(1.8 \% \pm 1.8 \%)$ during M II. During PM and Pre-M, the TOC content was $4.1 \% \pm 5.6 \%$ and $3.7 \% \pm 2.3 \%$ respectively (Figure $4 a-d$ ).

The sediment chlorophyll $a$ during M I, PM, Pre-M and $\mathrm{M}$ II was $0.22 \pm 0.1,2.9 \pm 1.2,1.6 \pm 0.7$ and $1.4 \pm$ $0.8 \mathrm{mg} \mathrm{m}^{-2}$ respectively (Figure $4 a-d$ ). The sediment chlorophyll $a$ was maximum during PM followed by Pre$\mathrm{M}$, indicating that the chlorophyll $a$ content was higher during non-monsoon season (Figure $4 a-d$ ).

\section{Seasonal variation in the abundance of macrobenthic organisms}

The macrobenthic organisms in Paradip port comprised Annelida (Polychaeta and Oligochaeta), Arthropoda (Pantopoda, Amphipoda and Isopoda), Mollusca (Bivalvia) and Echinodermata (sea anemones and brittle stars). The polychaetes were the most common and abundant organisms during all seasons. Among the 30 macrobenthic forms, 20 were polychaetes contributing more than $70 \%$ to the total macrobenthic abundance. Polychaetes belonging to genera Mediomastus and Cossura were observed during all seasons. The maximum abundance of macrobenthos was during M I (1893 no. $\mathrm{m}^{-2}$ ), followed 

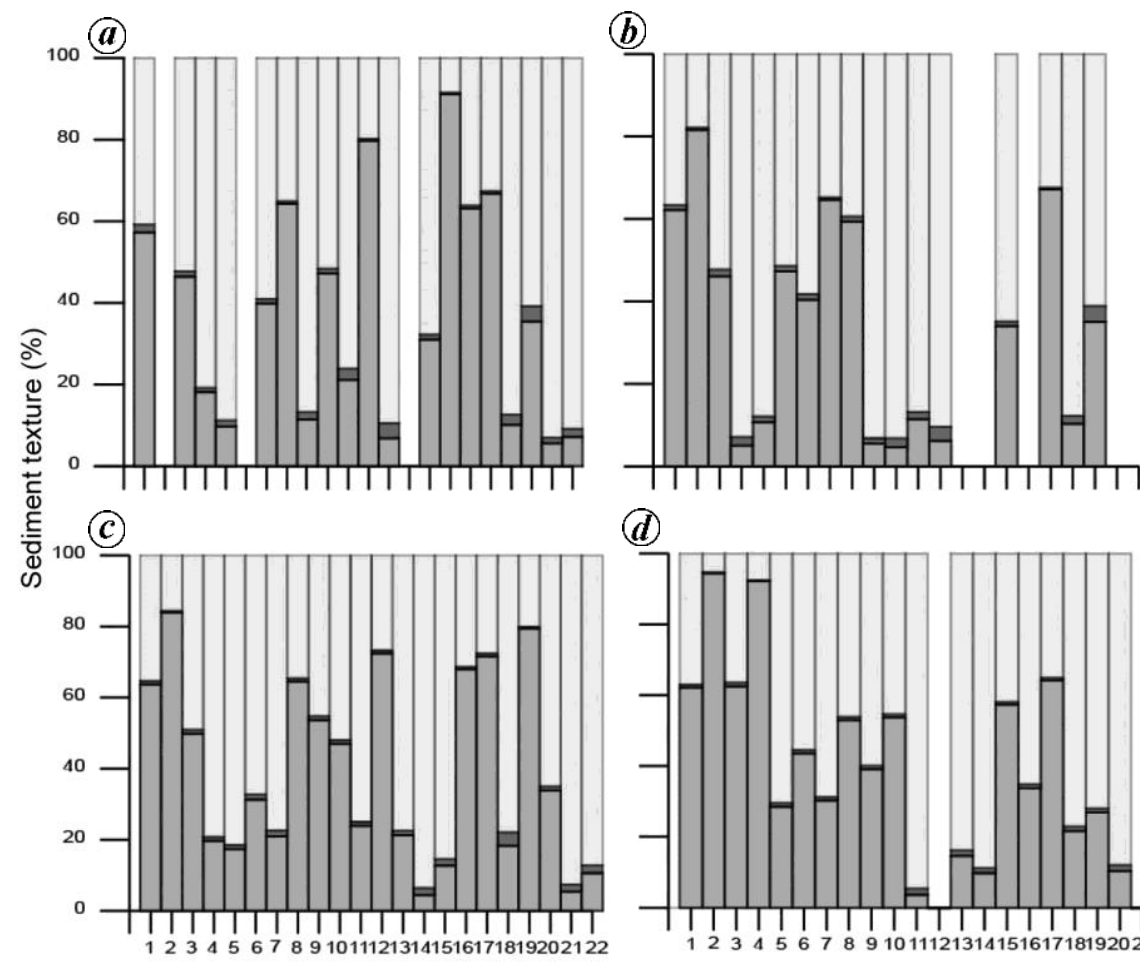

(d)

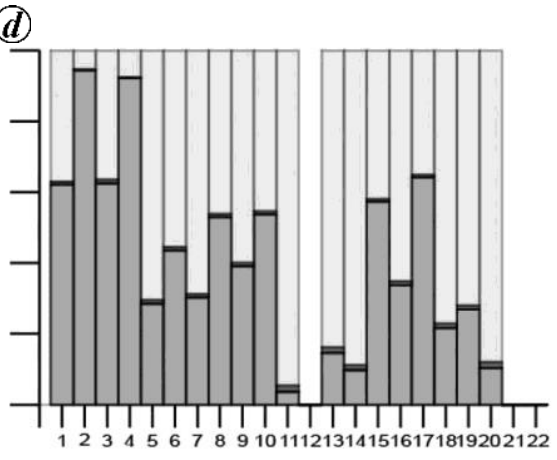

Stations

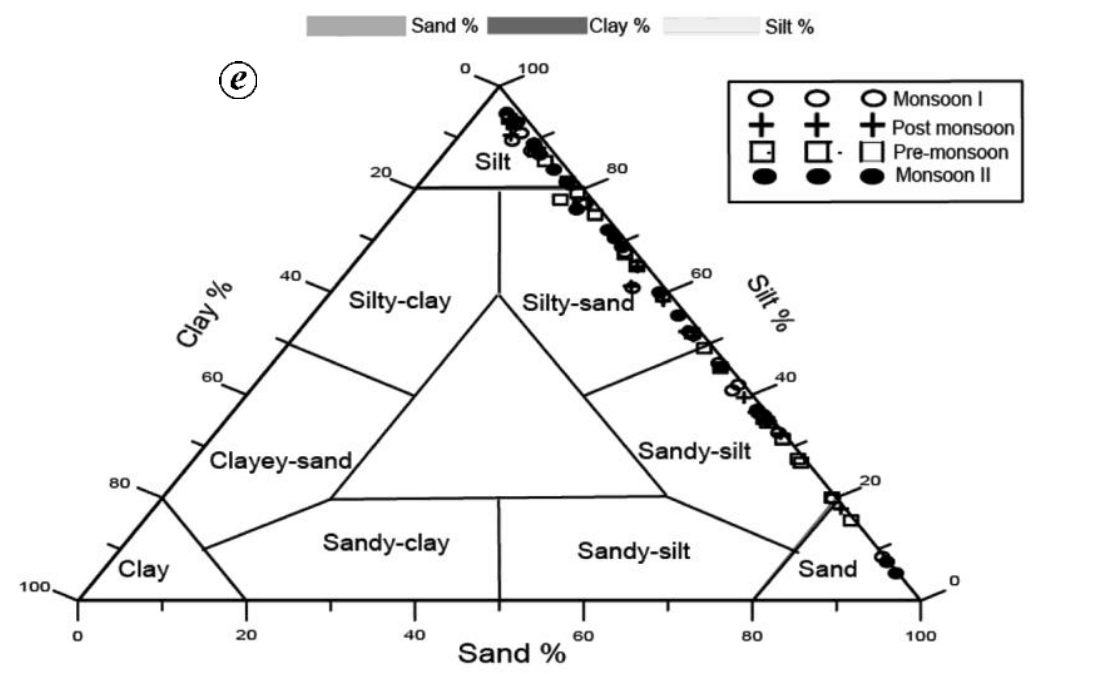

Figure 3. Variations in the sediment characteristics during different seasons: $\boldsymbol{a}$, monsoon I; $\boldsymbol{b}$, post monsoon; $\boldsymbol{c}$, pre-monsoon; $\boldsymbol{d}$, monsoon II. $\boldsymbol{e}$, Ternary plot at Paradip port.

by M II (1444 no. $\left.\mathrm{m}^{-2}\right)$, PM (922 no. $\left.\mathrm{m}^{-2}\right)$ and Pre-M (767 no. $\mathrm{m}^{-2}$ ) seasons (Table 3). During M I, maximum abundance of macrobenthos was at stations S06 (323 no. $\left.\mathrm{m}^{-2}\right)$ and S11 (446 no. $\mathrm{m}^{-2}$ ); during PM at station S04 (122 no. $\left.\mathrm{m}^{-2}\right)$; during Pre-M at S18 (216 no. $\mathrm{m}^{-2}$ ) and during M II at S12 (324 no. $\mathrm{m}^{-2}$; Table 3$)$. The biomass was maximum during M I $\left(12,313 \mathrm{mg} \mathrm{m}^{-2}\right)$, followed by M II (9528 mg. $\mathrm{m}^{-2}$ ), PM (3596 $\mathrm{mg} \mathrm{m}^{-2}$ ), and it was minimum during Pre-M season (3050 $\mathrm{mg} \mathrm{m}^{-2}$ ).

The maximum biomass during M II was $5085 \mathrm{mg} \mathrm{m}^{-2}$ at $\mathrm{S} 11$ and minimum was $10.7 \mathrm{mg} \mathrm{m}^{-2}$ at S15 (Table 3). During PM and Pre-M seasons, the biomass was higher at
S04 (980 $\left.\mathrm{mg} \mathrm{m}^{-2}\right)$ and S18 (1562 $\left.\mathrm{mg} \mathrm{m}^{-2}\right)$, and low at S15 $\left(47 \mathrm{mg} \mathrm{m}^{-2}\right)$ and S07 (25 $\mathrm{mg} \mathrm{m}^{-2}$; Table 3).

During MI, the maximum abundance of polychaetes was contributed by the Cirratulidae, Tharyx sp. (447 no. $\left.\mathrm{m}^{-2}\right)$, followed by Mediomastus sp. (292 no. $\left.\mathrm{m}^{-2}\right)$ and Cossura sp. (232 no. $\mathrm{m}^{-2}$ ) along with organisms belonging to order Pantopoda (185 no. $\mathrm{m}^{-2}$; Figure $5 a$ ). The abundance of Prionospio sp. during this season was 155 no. $\mathrm{m}^{-2}$ (Figure $5 a$ ). Tharyx sp. contributed $21 \%$ to total macrobenthic abundance, with $14.1 \%$ by Mediomastus sp. and $11.2 \%$ by Cossura sp. (Figure $5 a$ ). Among the nonpolychaete taxa, Pantopoda contributed $9 \%$ followed by CURRENT SCIENCE, VOL. 119, NO. 1, 10 JULY 2020 

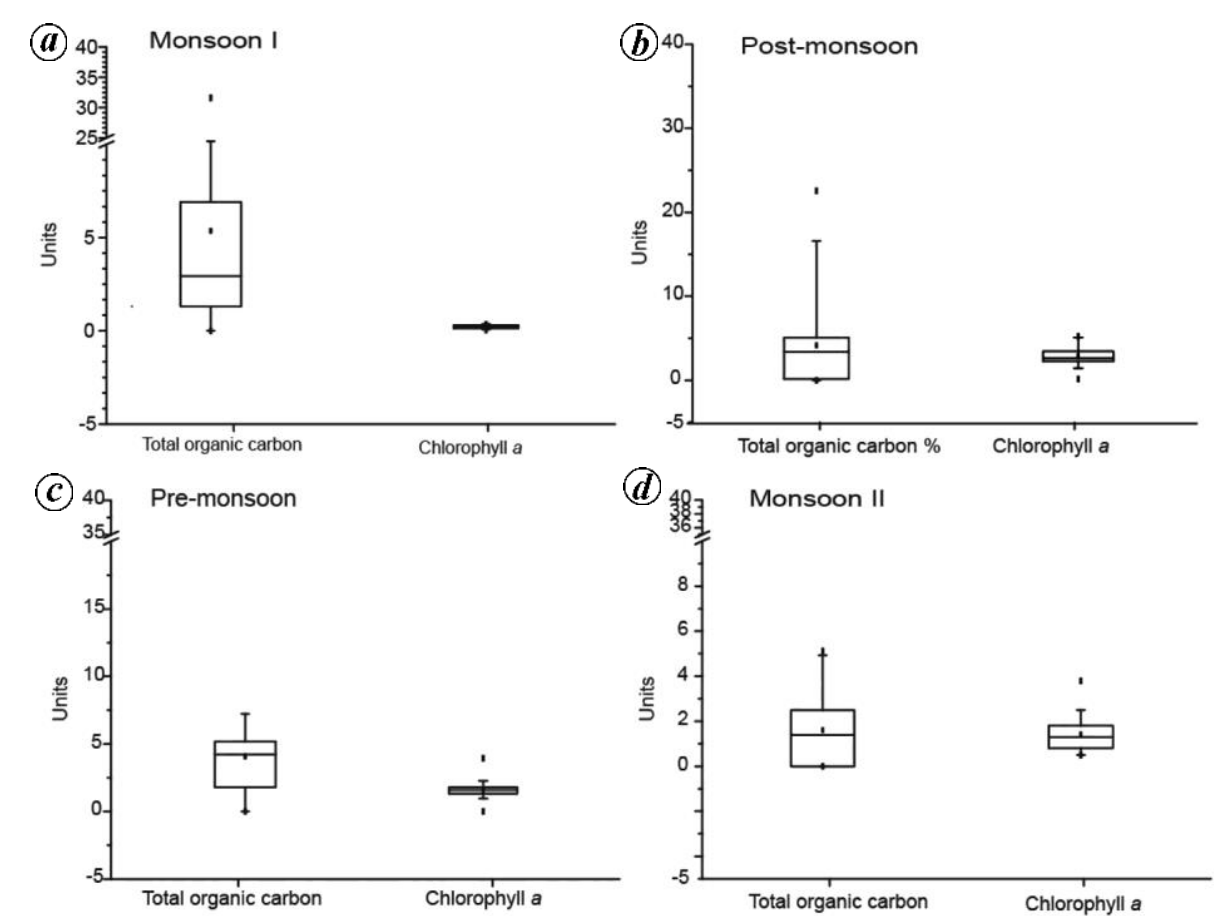

Figure $4 \boldsymbol{a}-\boldsymbol{d}$. Seasonal variations in the total organic carbon (\%) and sediment chlorophyll $a\left(\mathrm{mg} \mathrm{m}^{-2}\right)$ at Paradip port during different seasons.

Nototropis sp. and Iospilidae $(2.9 \%$ and $2.2 \%$ respectively) to the total macrobenthos abundance (Figure $5 a$ ). Stations S11, S06 and S08 showed higher abundance of macrobenthos, and Pantopoda was observed only at S11. At stations S02, S12, S18, S21 and S22, macrobenthos were not reported. Compared to $\mathrm{M} \mathrm{I}$, during PM the abundance of macrobenthos was less and the community was dominated by Tharyx sp. (at stations S01, S04, S12, S17 and S22) and Cossura sp. (at stations S04, S09, S12 and S14) with an abundance of 200 and 184 no. $\mathrm{m}^{-2}$ respectively (Figure $5 b$ and Table 3 ). The polychaetes Cossura longocirrata, Magelona sp. and Mediomastus sp. contributed considerably to the total abundance of macrobenthos (Table 3). The abundance and diversity of macrobenthos was minimum during Pre-M compared to other seasons. The most abundant group was Cirolanidae $\left(215\right.$ no. $\left.\mathrm{m}^{-2}\right)$ at $\mathrm{S} 18$. Among the polychaetes, Nephtys sp. was dominant (169 no. $\mathrm{m}^{-2}$ ) followed by Cossura sp. (38 no. $\mathrm{m}^{-2}$; Figure $5 c$ and Table 3 ). The other polychaetes found were Kirkegaardia sp., Tharyx sp., Magelona sp., Diopatra sp. and Prionospio sp. (Table 3 and Figure $5 c$ ). Monsoon seasons were more productive in terms of occurrence of macrobenthos compared to non-monsoon seasons in Paradip port. Tharyx sp. was the most abundant during M II with a total abundance of 339 no. $\mathrm{m}^{-2}$ and found in S10, S11, S12, S15, S16 and S17, followed by Mediomastus sp. (168 no. $\mathrm{m}^{-2}$ ) and Maldane sp. 169 no. $\mathrm{m}^{-2}$ (Figures $5 d$ and 6). The other common Polychaetes were Cossura longicerrata - 123 no. $\mathrm{m}^{-2}$, Lumbrineries sp. -123 no. $\mathrm{m}^{-2}$, Prionsopio sp. -61 no. $\mathrm{m}^{-2}$, Melinna sp. -46 no. $\mathrm{m}^{-2}$, Megalona sp. -77 no. $\mathrm{m}^{-2}$, Glycera sp. -61 no. $\mathrm{m}^{-2}$ and Paraonis sp. -61 no. $\mathrm{m}^{-2}$ (Figures $5 d$ and 6).

\section{Variation and species diversity in macrobenthos}

Margalef species richness $(d)$, Shannon-Weiner index $\left(H^{\prime}\right)$ and evenness $\left(J^{\prime}\right)$ were used to calculate species diversity index at the stations. The maximum number of species were encountered during $\mathrm{MI}$, and the correspondence values of the Shannon-Weiner index $\left(H^{\prime}\right)$ during $\mathrm{M} \mathrm{I}$ and M II are 1.9 and 1.5 followed by Pre-M (1.3) and PM (1.3) season respectively. Post-monsoon showed low species diversity and abundance compared to the other three seasons (Table 3 and Figures 5 and 6). BrayCurtis similarity index at $50 \%$ similarity level, M I and M II showed two and three groups, and the diversity and abundance were higher during the monsoon season compared to the other seasons (Table 4). Monsoon season showed maximum diversity and biomass of macrobenthos with high temperature and low salinity in near-bottom water compared to the other seasons (Tables 2 and 3; Figure 2). During M I, high diversity and least similarity among stations was observed (Table 4). The group I stations were dominated by Prionospio sp. (contribution to abundance $-7.5 \%$ ) and in group II, Tharyx sp. was abundant with $21.7 \%$ contribution to the total abundance while the other abundant species were Mediomastus sp. and Cossura sp. contributing $14.1 \%$ and $11.2 \%$ respectively 

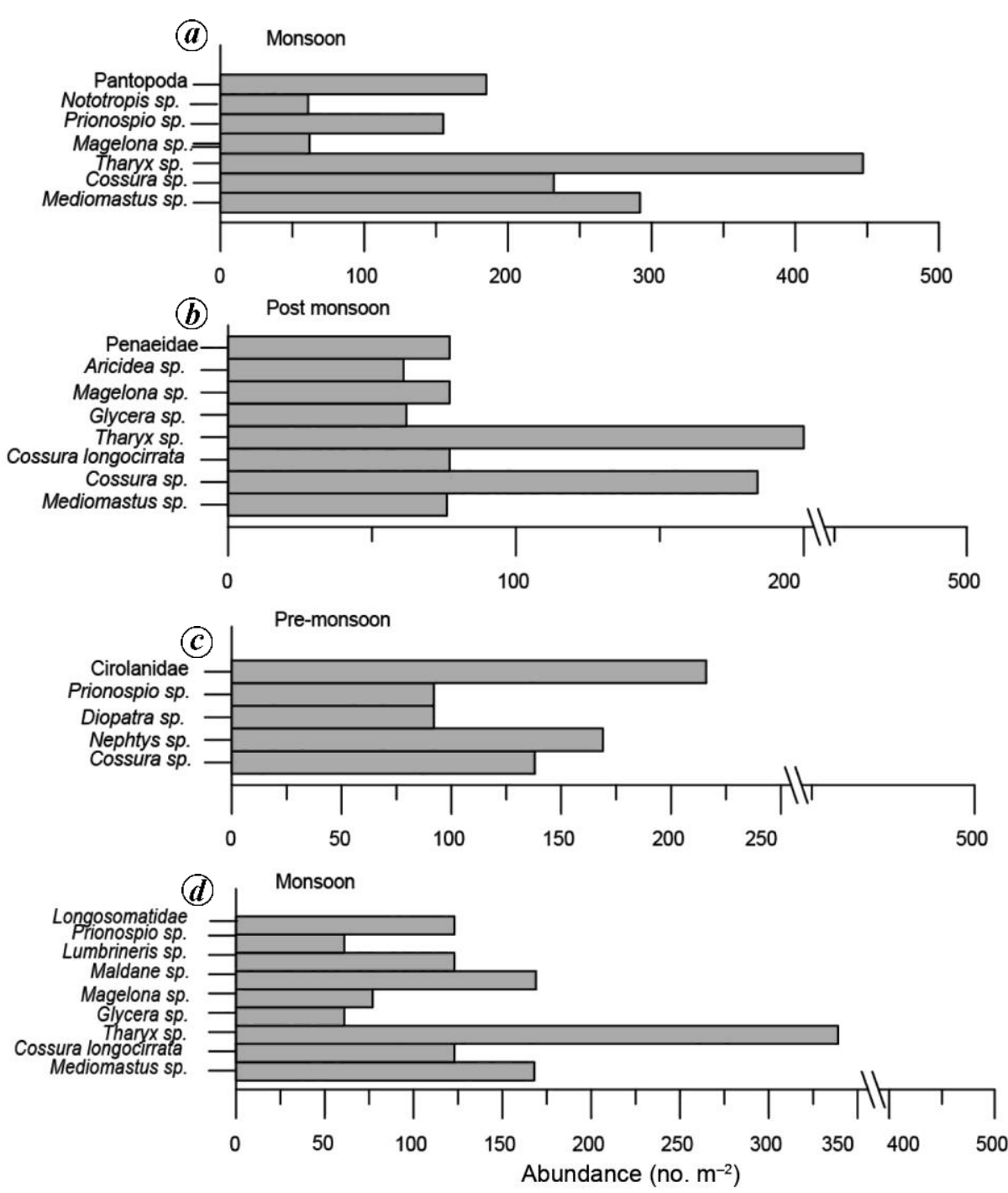

Figure $5 \boldsymbol{a}-\boldsymbol{d}$. Seasonal variation in the abundance $\left(\right.$ no. $\mathrm{m}^{-2}$ ) of dominant macrobenthic taxa at Paradip port.

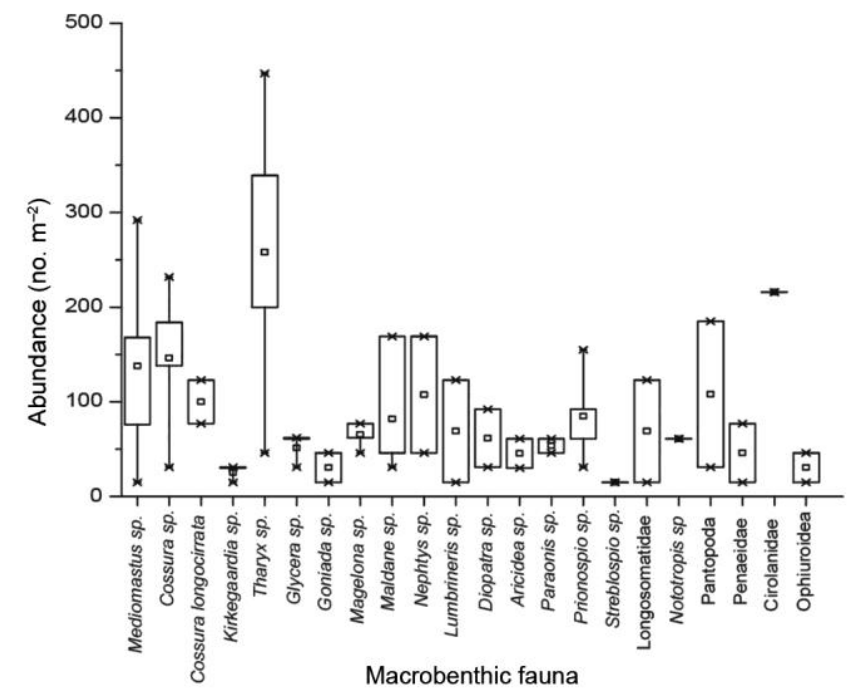

Figure 6. Box-plots depecting the abundance (no. $\mathrm{m}^{-2}$ ) of dominant macrobenthos at Paradip port.
(Figure $7 a$ ). During PM season, the similarity of organisms and their average abundance in groups I to IV was dominated by Tharyx sp. (20\%), Cossura sp. (18.4\%), Mediomastus sp. (7.6\%), Nephtys sp. (4.6\%) and Magelona sp. (7.7\%; Figure $7 b$ ). In the case of Pre-M season, average similarity among groups I, II and III was $36.6 \%, 61.5 \%$ and $50 \%$ respectively (Figure $7 c$ ). During M II, three groups were observed, with group I (stations S09, S11, S15 and S17), group II (stations S03 and S13) and group III (stations S01 and S08) having similarity of $66.6 \%, 66.6 \%$ and $54.9 \%$ respectively (Figure $7 d$ ).

CCA and redundancy analysis indicated sediment characteristics and TOC to play an important role in influencing the community structure of benthic organisms during different seasons at different stations (Figure $8 a-d$ ). Length of gradient value $>2$ was obtained during MI and M II seasons and during PM and Pre-M season it was $<2$. The correlation percentage between macrobenthic abundance and the environmental variables during M I and 


\section{RESEARCH ARTICLES}

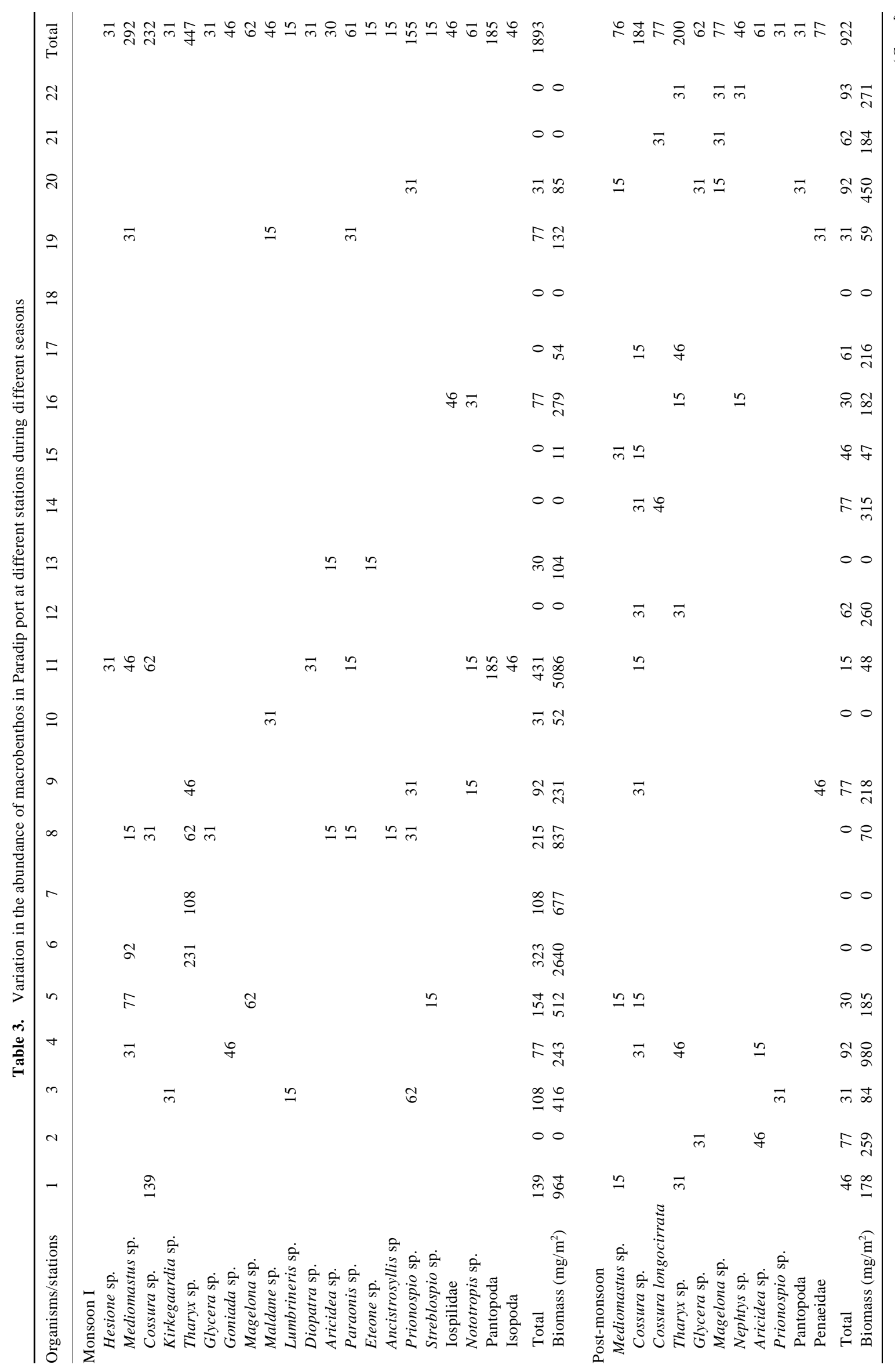




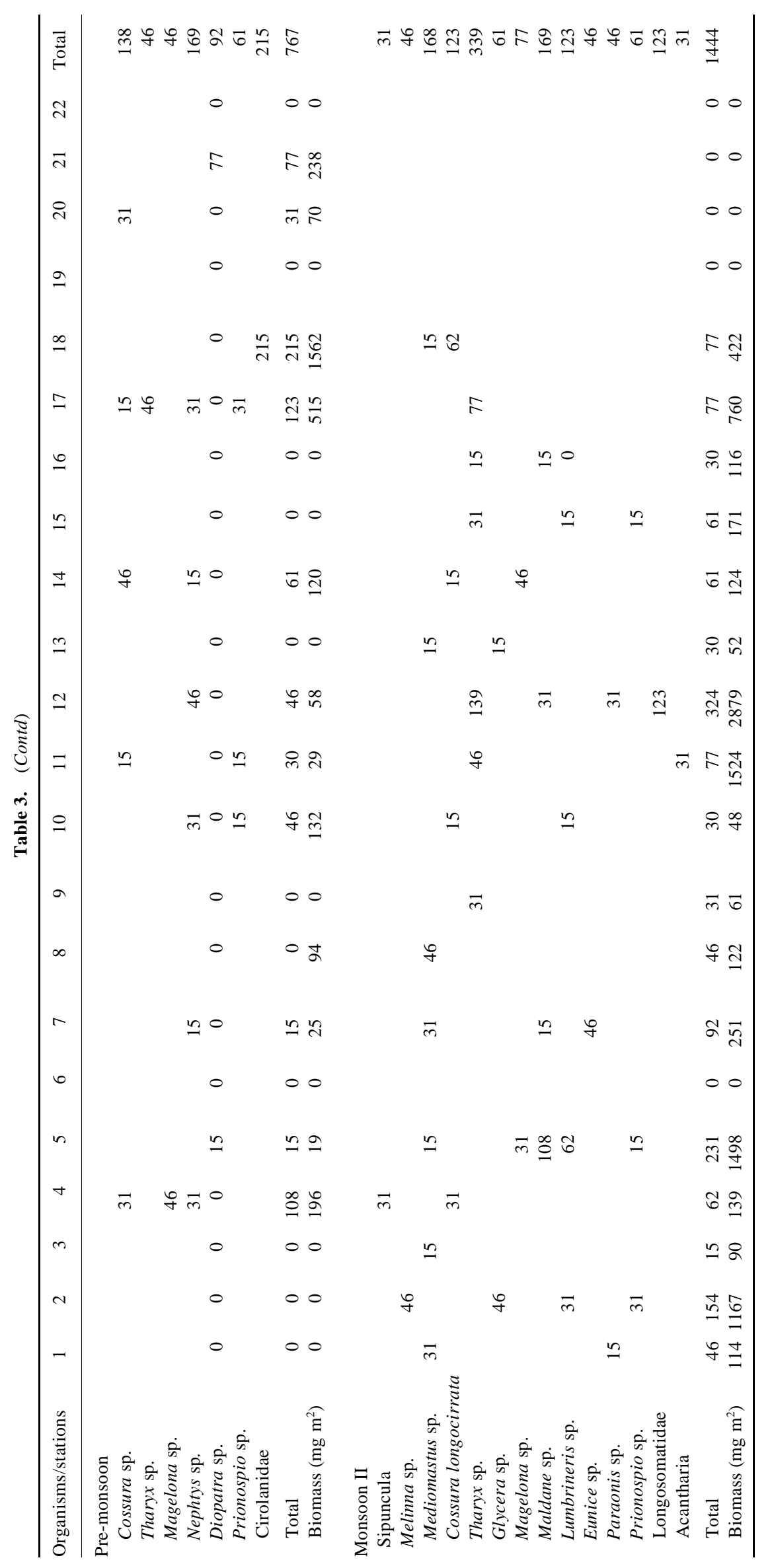




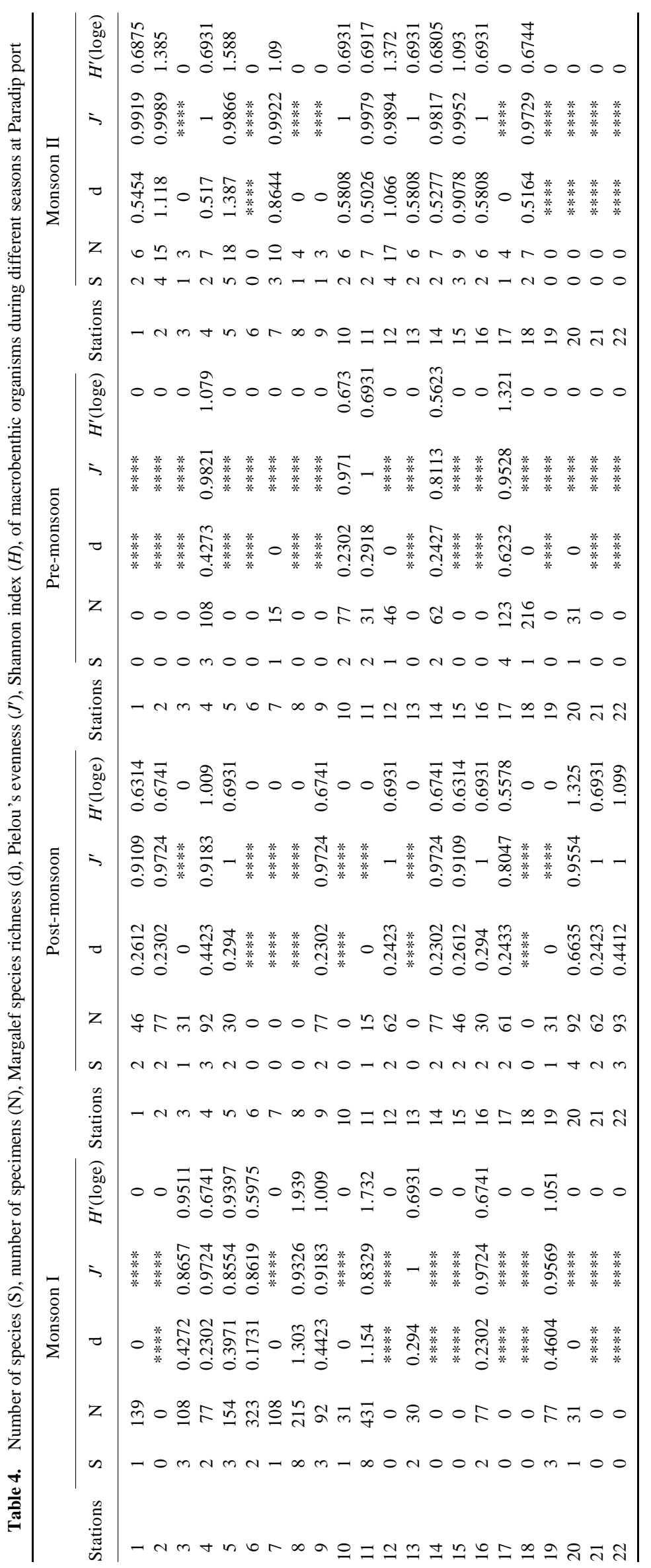



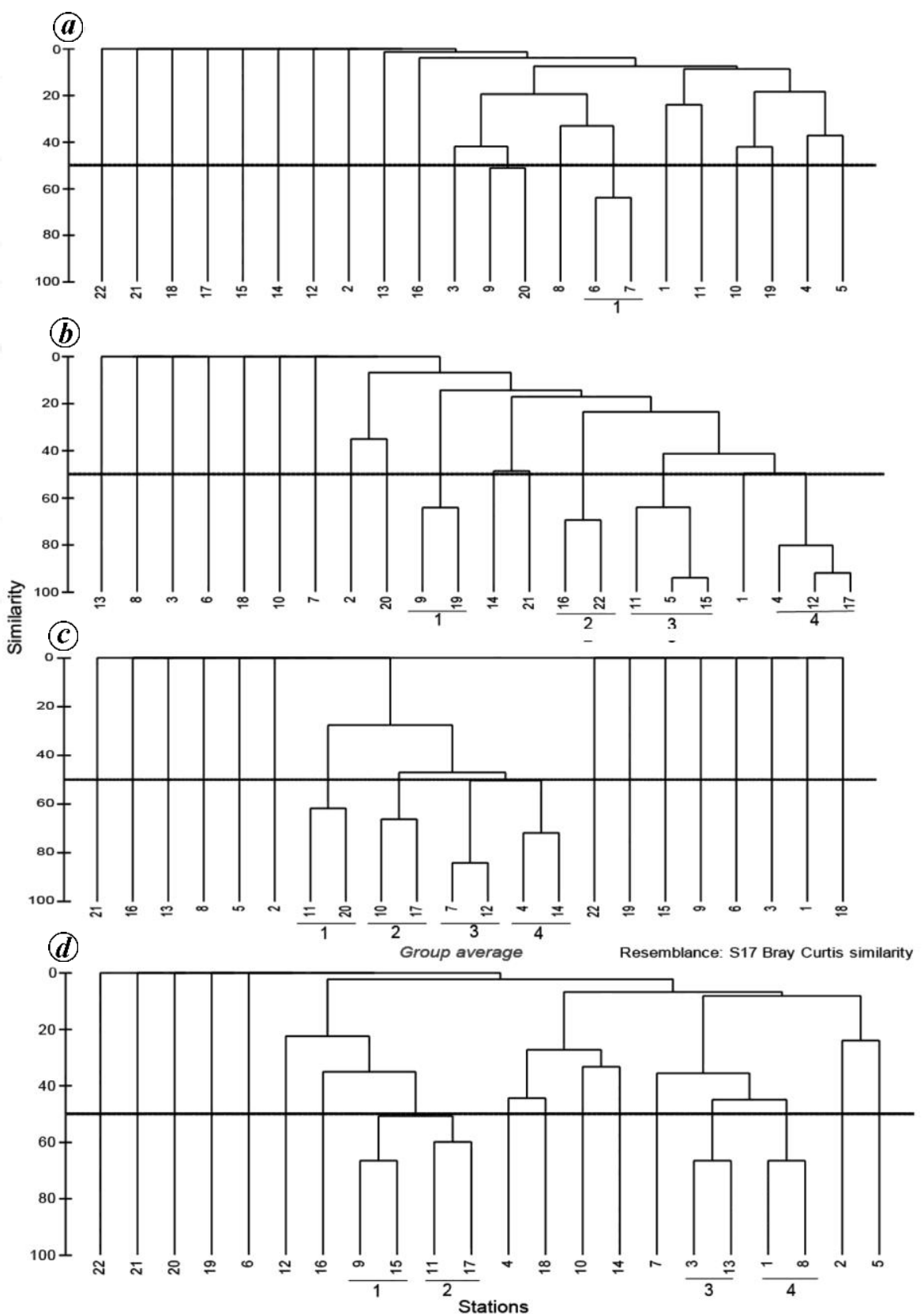

Figure 7. Dendrogram for hierarchical clustering of macrobenthic polychaetes with Bray-Curtis similarity indices during different seasons: $(\boldsymbol{a})$ monsoon I, $(\boldsymbol{b})$ post-monsoon, $(\boldsymbol{c})$ pre-monsoon and $(\boldsymbol{d})$ monsoon II.

M II was 81.4 and 96.7, and during PM and Pre M it was 92.6 and 82.8 respectively. CCA indicated that during MI (Figure $8 a$ ) sand, near-bottom water temperature and TOC influenced the abundance of organisms such as Prionospio sp., Lumbrineris sp. and Kirkegaardia sp., whereas silt, organic nitrogen and DO positively influenced Goniada sp., Magelona sp., Cossura sp. and Streblospio sp. The polychaetes Mediomastus sp. and Eteone sp. were not influenced by the environment variables. During PM season, Tharyx sp., Penaeidae and Aricidea sp. were positively influenced by silt, DO and salinity. Mediomastus sp., Magelona sp., Glycera sp. and Panto- poda were found to survive well in clayey sediment and in low DO, salinity and silt content (Figure $8 b$ and Table 3 ). The redundancy analyses during Pre-M showed that sand and bottom-water temperature positively influenced Tharyx sp., Prionospio sp. and Nephtys sp., and they were negatively influenced by TOC, organic nitrogen, silt and chlorophyll $a$ (Figure $6 c$ and Table 3 ). The polychaetes Magelona sp. and Cossura sp. thrived well in high organic carbon and nitrogen-rich silty or sandy sediments. The CCA plot during M II showed that silt, chlorophyll $a$, organic nitrogen and silicate contributed to higher abundance of Tharyx sp., Maldane sp., Paraonis sp., 

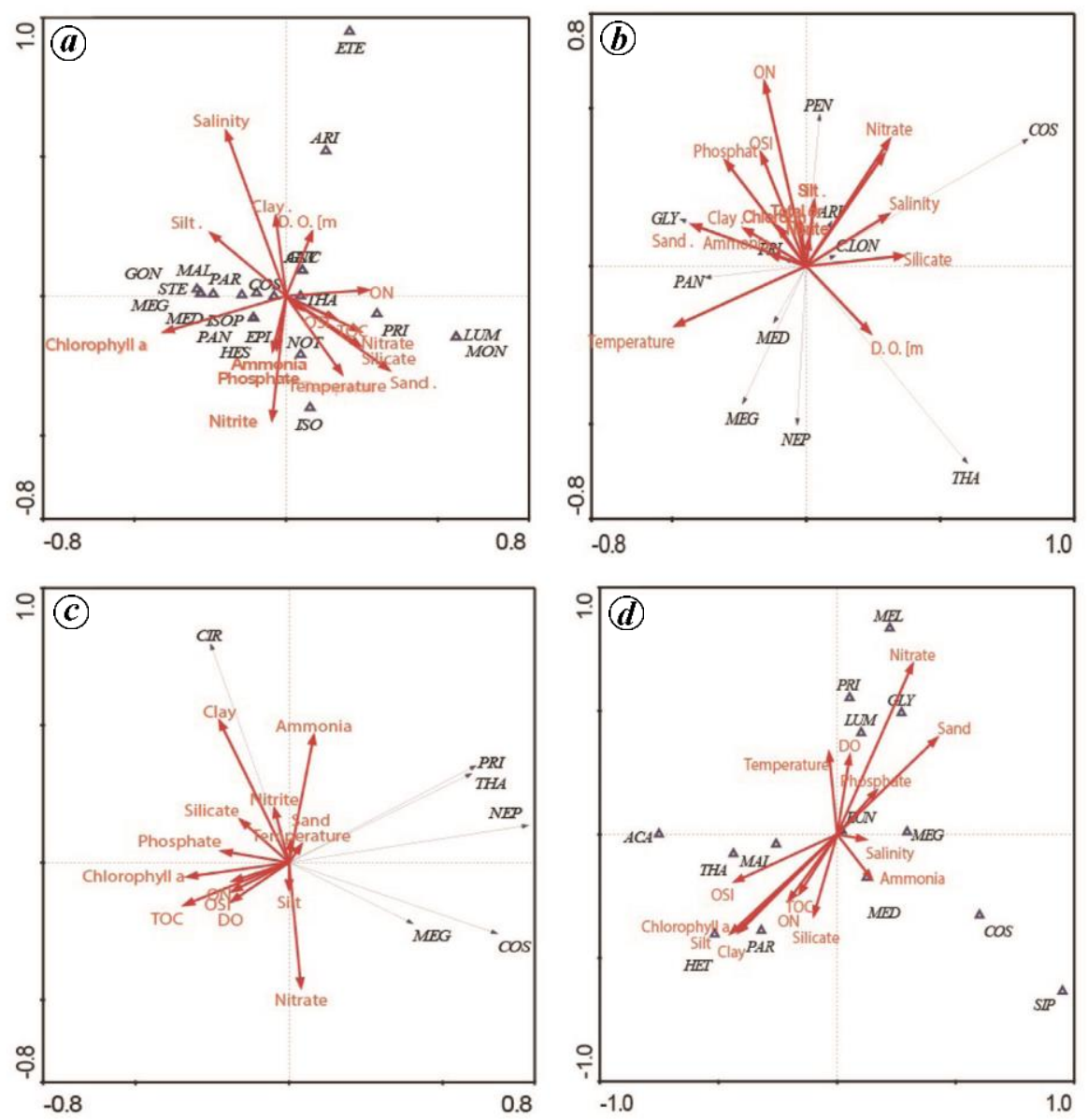

Figure 8. Canonical correspondence analysis (CCA) and RDA plots illustrating the correlation between environmental parameters and sediment characteristics and macrobenthos species during different seasons: $(\boldsymbol{a})$ monsoon I, $(\boldsymbol{b})$ post-monsoon, $(\boldsymbol{c})$ pre-monsoon and $(\boldsymbol{d})$ monsoon II at Paradip port. (ANC, Ancistrosyllis sp.; ARI, Aricidea sp.; COS, Cossura sp.; C.LON, Cossura longocirrata; ETE, Eteone sp.; EUN, Eunice sp.; EPI, Diopatra sp.; GLY, Glycera sp.; GON, Goniada sp.; HES, Hesione sp.; LUM, Lumbrineris sp.; MAL, Maldane sp.; MED, Mediomastus sp.; MEG, Magelona sp.; MEL, Melinna sp., MON, Kirkegaardia sp.; NEP, Nephtys sp.; NOT, Nototropis sp.; PAR, Paraonis sp.; PRI, Prionospio sp.; STR, Streblospio sp.; THA, Tharyx sp.; ACA, Acantharia, CIR, Cirolanidae; HET, Longosomatidae; ISO, Iospilidae; ISOP, Isopoda; PAN, Pantopoda; PEN, Penaeidae and SIP, Sipuncula; ON, Organic nitrogen (\%); OSI, Organic sediment index (\%); DO, Dissolved oxygen (mg m) and TOC, Total organic carbon $(\%)$ ).

Longosomatidae and Acantharia, while Errantiate polychaetes, Glycera sp., Lumbrineris sp. and Melinna sp. could adapt to sandy sediments with high temperature and DO (Figure $8 d$ and Table 3 ).

\section{Discussion}

Studies on the biodiversity of benthic organisms from the tropical regions are limited when compared to higher altitudes $^{23}$ and the same is true for Paradip port situated on the east coast of India ${ }^{24}$. The study of macrobenthic organisms is important to understand and establish a database for the region to improve our understanding on distribution, abundance, diversity and other characteristics of macrobenthic organisms in the marine environment ${ }^{25}$, as they play an important role in the food web dynamics and ecological functioning of the benthic ecosystems. The changes occurring in these parameters can lead to disturbance in the benthic faunal diversity and abundance. In the present study, macrobenthic community structure and abundance varied with the seasons, associated with changes in salinity (lower in monsoon and higher in nonmonsoon seasons), temperature, DO and sediment characteristics. The sediment quality is the most important parameter for seasonal and spatial distribution and diversity of benthic organisms. The various properties related to sediment quality are permeability, penetrability that is controlled by erosion, resuspension and water content in the sediments ${ }^{26}$. The sediment quality in Paradip port indicated that there were limited changes in the spatiotemporal variation in the sediment texture which was 
mostly dominated by silt followed by sand with minimum contribution of clay. The TRIX analysis for bottom water showed that the near-bottom water quality was also good and rich in organic matter, indicating healthy bottomwater conditions ${ }^{27}$. There was a wide range in salinity variation (25-34) during the non-monsoon and monsoon seasons, resulting in the euryhaline species such as Cossuridae and Cirratulidae to adapt and survive during monsoon and stenohaline organisms such as isopods and crustaceans (Penaeidae) during the non-monsoon seasons. The near bottom sea-water nutrients were higher during pre-monsoon (summer) than in the other seasons due to gradual increase in temperature ${ }^{28}$. The present study area also showed increased nutrient levels during premonsoon compared to monsoon and post-monsoon seasons.

The organic carbon enrichment was high in Paradip port especially during M I and PM and it was low during Pre-M and M II, and such an increase in organic carbon in the sediments leads to hypoxic conditions as well as a decrease in the abundance and diversity of benthic organisms ${ }^{29}$. The stations with high organic content in the study area were either dominated by the indicator species or had lower abundance of macrobenthos. The distribution of organic carbon also varied in the surface sediments with stations along with changes in the sand-silt content, as organic carbon content was high in siltdominated areas. The finer silt particles accumulated higher organic carbon content due to the lack of disturbance in the sediments. There was a dominance of subsurface dwelling polychaetes, which are biological indicators of high organic matter in the sediments. This high organic matter content may be due to plant material and faeces that settle down, and such organic matter is removed from the water column and at the sedimentwater interface by the benthic fauna. The deposited organic material either becomes part of particulate organic matter, which is taken in by benthic fauna or directly ingested by deposit feeders ${ }^{30}$. The temporal changes such as salinity, sediment size gradient and other environmental stresses associated with organic carbon enrichment lead to the succession of different species ${ }^{31}$. The present study also showed changes in the diversity pattern of macrobenthos due to seasonal variation along with increased organic carbon input. The most common organisms reported were Tharyx sp., Prionospio sp., Cossura sp. and Magelona sp. in Paradip port, and these are called opportunistic species and are well-known pollution indicators $^{32}$. These organisms are mostly found in stations with high organic carbon in the sediments, indicating that they may be surface or subsurface deposit feeders ${ }^{33}$. An earlier study indicated higher abundance of Prionospio sp. in a semi-polluted (moderate organic carbon) region of the Visakhapatnam harbour ${ }^{5}$. It has been reported that Prionospio sp. and few other species burrow in sand and are capable of constructing tubes in which they hide and which also protects them from predators, indicating their subsurface deposit-feeding habit ${ }^{34}$. With regard to properties of sediment dynamics, it has been suggested that high silt-clay fraction in the sediments contains more food particles which are commonly composed of decomposable organic constituents and sustain deposit-feeding benthic organisms ${ }^{5,27,35,36}$. Organisms belonging to Cossura sp. are mostly burrowers in the soft sediment dominated by high silt.

Higher abundance of deposit feeders belonging to genus Cossura was reported in a high silt area at Visakhapatnam port ${ }^{5}$. Prionospio sp. has been reported as an indicator of organic enrichment in subtidal areas, which is an inhabitant of the subsurface region of the sediments ${ }^{7}$. An earlier study has reported that subsurface deposit-feeding polychaetes such as Mediomastus sp., Tharyx sp. and Cossura sp. are capable of feeding on freshly settled organic carbon and on aged organic matter in the sediments ${ }^{37}$. The Magelona sp. is a subsurface deposit feeder and its feeding activity usually occurs below the surface $^{38}$. Spatial variation in the benthic community is observed mostly in the estuaries and bays, under extreme or abnormal circumstances of organic matter overloading in the coastal waters leading to disturbance in the faunal community $^{39}$. They are also mostly deposit feeders and are present in sandy-silt sediments with high total organic carbon, as observed in Mediomastus sp. ${ }^{38}$.

Similar conditions were observed in the Paradip port and Mediomastus sp. which is one of the most abundant sedentary polychaetes present in the fine-grained sandy habitats dominated by silt with high organic matter. The individuals of Mediomastus sp. were present during all the seasons. These are non-selective feeders as they engulf food directly from the sediments ${ }^{40}$ and this may be related to less disturbance in the sediments as they are observed during all the seasons. Cossura sp. is a stresstolerant macrobenthic polychaete which is a suspension feeder and prefers sandy and fine silty sediments. It is a burrower which prefers soft sediments with high silt, as reported earlier ${ }^{41}$. The other dominant polychaete, Nephtys sp. found during all the seasons is an active predator that prefers fine sandy sediments, and studies have reported higher abundance of these organisms in fine sandy sediments ${ }^{40,41}$. The hypoxia and pollutiontolerant polychaetes Tharyx sp. and Prionospio sp., which are deposit feeders were observed during all the seasons, thus indicating the health of the ecosystem. Even though Tharyx sp. is a selective feeder which inhabits the mudcoloured tubes, it is found in highly polluted areas ${ }^{16}$.

During monsoon season, the observed high organic carbon content can be attributed to collapse and sinking of phytoplankton from the surface waters ${ }^{42}$. The presence of Spionidae, Prionospio sp. and Cossuridae, Cossura sp. in the sediments shows sediment instability and disturbed environment, and both these species are deposit feeders that feed on fresh surface organic matter ${ }^{43,44}$. The diversity 
of macrobenthos is limited in Paradip port, as high organic matter content promotes the abundance of tolerant species and lowers the abundance of sensitive spe$\operatorname{cies}^{29}$, and this leads to reduction in their diversity and abundance. There is also another possibility of macrobenthic assemblages in high organic carbon sediments, where black carbon contributes more to organic carbon content present in the sediments ${ }^{45}$. The presence of indicator species of pollution, viz. Prionospio sp., Streblospio sp., Mediomastus sp. and Tharyx sp. in this study indicates that they thrive in low oxygen and high organic load ${ }^{46}$.

Lumbrineris sp. are carnivores or carrion feeders and they prey on other polychaetes, Nemertea, Crustacea and Bivalvia $^{16}$. It is possible that disturbance in the surface sediments during monsoon season may lead to the exposure of burrowing organisms and this may be the reason for observing Lumbrineris sp. during the monsoon season. The Magelona sp. is also found during all seasons. Studies on Magelona indicate that they are non-selective surface deposit feeders and also alter their feeding mode to suspension feeding ${ }^{16}$. In respect to their non-selective feeding behaviour and the presence of sufficient organic matter in the study area, Magelona sp. is present during all the seasons despite variations in its abundance. There is a difference in species abundance and diversity in accordance to the seasonal changes in Paradip port, with higher abundance during the monsoon season ${ }^{23}$. The life cycle of a tropical macrobenthic organism integrates with the monsoon and this results in seasonal differences in occurrence and abundance of such organisms. A previous study on Indian ports shows reduction in the macrobenthic species composition, density and biomass due to dredging and anthropogenic activities, as observed in Cochin port ${ }^{47}$. In Visakhapatnam port, a coastal ecosystem, the macrobenthic community composition varied due to various levels of pollutant accumulation in the sediments spatially showing the difference in benthic community in the port ecosystem ${ }^{5}$. The loss of macrobenthic communities and their rapid recovery in these stations are due to the migration of these fauna from the nearby sediment patches that are not leading to reclamation of macrobenthos under suitable conditions, as observed in Cleveland $\mathrm{Bay}^{48}$.

The previous studies showed that due to variations in the sediments, the macrobenthic populations increased or decreased in the small port ecosystems as observed in the present study. The presence of higher organic carbon in sediments also causes a depletion in the species diversity, abundance and biomass ${ }^{49}$, resulting in proliferation of opportunistic species. The present study shows higher organic carbon in the study area leading to the depletion in diversity and also survival of pollution-tolerant species, albeit their count. The present study also showed that the Paradip port environment is influenced by seasonal variation mostly brought in by the monsoons and anthropogenic activities: however, healthy bottom-water quality and high amount of organic load accumulated in the sediments lead to the survival and proliferation of indicator macrobenthos species.

1. Snelgrove, P. V. R., The biodiversity of macrofaunal rganismos in marine sediments. Biodivers. Conserv., 1998, 7(9), 1123-1132.

2. Stuart, G., John, E. and Michael, Ecology of marine sediments: from science to management environmental impacts of shipping. In Handbook of Transport and the Environment (eds Hensher, D. A. and Button, K. J.), Elsevier, Oxford, 2003, pp. 279-290.

3. Musale, A. S. and Desai, D. V., Distibution and abundance of macrobenthic polychaetes along the South Indian coast. Environ. Monit. Assess., 2011, 178(1-4), 423-436.

4. Darbra, R. M., Ronza, A., Stojanovic, T. A., Wooldridge, C. and Casal, J., A procedure for identifying significant environmental aspects in sea ports. Mar. Pollut. Bull., 2005, 50, 866-874.

5. Musale, A. S., Desai, D. V., Sawant, S. S., Venkat, K. and Anil, A. C., Distribution and abundance of benthic macroorganisms in and around Visakhapatnam Harbour on the east coast of India. J. Mar. Biol. Assoc. UK, 2015, 95(2), 215-231.

6. Danulat, E., Muniz P., Garcia Alonso, J. and Yannicelli, B., First assessment of the highly contaminated harbour of Montevideo, Uruguay. Mar. Pollut. Bull., 2005, 44, 551-576.

7. Elias, R., Palacios, J. R., Rivero, M. S. and Vallarino, E. A., Short term responses to sewage discharge and storms of subtidal sandbottom macrozoobenthic assemblages off Mar del Plata City, Argentina (SW Atlantic). J. Sea Res., 2005, 53, 231-242.

8. Ingole, B., Sivadas, S., Nanajkar, M., Sautya, S. and Nag, A., A comparative study of macrobenthic community from harbours along the central west coast of India. Environ. Monit. Assess., 2009, 154(1-4), 135-146.

9. Rilov, G. and Crooks, J. A., Marine bioinvason: conservation hazards and vehicles for ecological understanding. In Biological Invasions in Marine Ecosystems: Ecological, Management and Geographical Perspectives (eds Rilov, G. and Crooks, J. A.), Springer, Berlin, 2009, 204, pp. 3-11.

10. Mandal, S. and Harkantra, S. N., Changes in the soft-bottom macrobenthic diversity and community structure from the ports of Mumbai, India. Environ. Monit. Assess., 2013, 185, 653-672.

11. Walker, T. D. and Valentine, J. W., Equilibrium models of evolutionary species diversity and the number of empty niches. Am. Nat., 1984, 124, 887-899.

12. Anil, A. C., Venkat, K., Sawant, S. S., Dileepkumar, M., Dhargalkar, V. K. and Raimaiah, N., Marine bioinvasion: concern for ecology and shipping. Curr. Sci., 2002, 83, 214-218.

13. Parsons, T. R., Maita, Y. and Lalli, C. M., A Manual of Chemical and Biological Methods for Seawater Analysis, Pergamon Press, Oxford, 1984, p. 173.

14. Fauvel, P., The fauna of India including Pakistan, Cylon, Burma and Malaya: Annelida, Polychaeta, The Indian Press, Allahabad, 1953, pp. 1-507.

15. Day, J. H., A monograph on the polychaeta of southern Africa. Part I (Errantia) and II (Sedentaria). Thrustees of the British Museum (Natural History), London, 1967.

16. Fauchald, K. and Jumars, P., The diet of worms: a study of polychaete feeding guilds. Oceanogr. Mar. Biol.: An Аnпи. Rev., 1979, 17, 194-284.

17. Mason, W. T., Lewis, P. A. and Weber, C. I., An evaluation of benthic macroinvertebrate biomass methodology-Part 2 field assessment and data evaluation. Environ. Monit. Assess., 1985, 5(4), 399-422.

18. Kristensen, E. and Andersen, F., Determination of organic carbon in marine sediments comparison of two CHN - analyzer methods. 1987, 109, 15-23.

19. Byers, S. C., Mills, E. L. and Stewart, P. L., A comparison of methods of determining organic carbon in marine sediments, with 


\section{RESEARCH ARTICLES}

suggestions for a standard method. Hydrobiologia, 1978, 58, 43-47.

20. Buchanan, J. B., Sediment analysis. In Methods for the Study of Marine Benthos (eds Holme, N. A. and McIntyre, A. D.), Blackwell Scientific, Oxford, 1984, pp. 41-65.

21. Clarke, K. R. and Gorley, R. N., PRIMER v6: user manual tutorial. PRIMER-E Ltd., Plymouth, UK, 2006, p. 190.

22. Vollenweider, R. A., Giovanardi, F., Montanari, G. and Rinaldi, A., Characterization of the trophic conditions of marine coastal eaters with special reference to the nw Adriatic sea: proposal for a trophic scale, turbidity and generalized water quality index. Environmetrics, 1998, 9, 329-357.

23. Along, D. M., Ecology of tropical soft-bottom benthos: a review with emphasis on emerging concepts. Rev. Biol. Trop., 1989, 37, 85-100.

24. Sharma, S. Das, Nayak, L., Panda, C. R., Pati, M. P. and Samantaray, S., A review on benthic study along Odisha Coast, east coast of India : a neglected. J. Crit. Rev., 2016, 3, 27-32.

25. Warwick, R. M. and Ruswahyuni, Comparative study of the structure of some tropical and temperate marine soft-bottom macrobenthic communities. Mar. Biol., 1987, 95, 641-649.

26. Sarkar, S. K., Bhattacharya, A., Giri, S., Bhattacharya, B., Sarkar, D., Nayak, D. C. and Chattopadhaya, A. K., Spatiotemporal variation in benthic polychaetes (Annelida) and relationships with environmental variables in a tropical estuary. Wetl. Ecol. Manage., 2005, 13(1), 55-67.

27. Jayaraj, K. A., Josia, J. and Kumar, P. K. D., In faunal macrobenthic community of soft bottom sediment in a tropical shelf. $J$. Coast. Res., 2008, 243, 708-718.

28. Faragallah, H. M., Askar, A. I., Okbah, M. A. and Moustafa, H. M., Physico-chemical characteristics of the open Mediterranean sea water for about $60 \mathrm{~km}$ from Damietta harbor, Egypt. J. Ecol. Nat. Environ., 2009, 1, 106-119.

29. Pearson, T. H. and Rosenberg, R., Macrobenthic succession in relation to organic enrichment and pollution of the marine environment. Oceanogr. Mar. Biol. Annu. Rev., 1978, 16, 229-311.

30. Snelgrove, P. V. R., Royal Swedish Academy of Sciences the importance of marine sediment biodiversity in ecosystem processes the importance of marine sediment biodiversity in ecosystem processes. Source: Ambio, 1997, 26, 578-583.

31. Ansari, Z. A., Ingole, B. S. and Abidi, S. A. H., Organic enrichment and benthic fauna - some ecological consideration. Indian J. Geo-Mar. Sci., 2014, 43, 554-560.

32. Sivadas, S., Ingole, B. and Nanajkar, M., Benthic polychaetes as good indicators of anthropogenic impact. Indian J. Geo-Mar. Sci., 2010, 39, 201-211.

33. Rosenberg, R., Benthic marine fauna structured by hydrodynamic processes and food availability. Neth. J. Sea Res., 1995, 34, 303-331.

34. Moritz, D., Composition and distribution of the macrozoobenthic communities on the shelf off Angola. Master Thesis Marine Biology, University of Rostock, Germany, 2012.

35. Sanders, H. L., Benthic studies in Buzzard's Bay. I. Animalsediment relationships. Limnol. Oceanogr., 1958, 3, 245-258.

36. Sanders, H. L., Benthic studies in Buzzards Bay, III. The structure of the soft bottom community. Limnol. Oceanogr., 1960, 5, $138-153$.

37. Long, E. R., Dutch, M. E., Aasen, S., Welch, K. I., Partridge, V. A. and Shull, D. H., Relationships between the composition of the benthos and sediment and water quality parameters in Hood Ca- nal: Task IV - Hood Canal Dissolved Oxygen Program, Washington State Department of Ecology, Publication No. 07-03-040. www.ecy.wa.gov/biblio/0703040.html

38. Jumars, P. A., Dorgan, K. M. and Lindsay, S. M., Diet of worms emended: an update of polychaete feeding guilds. Annu. Rev. Mar. Sci., 2015, 7, 497-520.

39. Mendez, N., Trophic categories of soft-bottom epibenthic deepsea polychaetes from the southeastern Gulf of California (Mexico) in relation with environmental variables. Pan. Am. J. Aquat. Sci., 2013, 8(4), 299-311.

40. Van Hoey, G., Degraer, S. and Vincx, M., Macrobenthic community structure of soft-bottom sediments at the Belgian Continental Shelf. Estuarine Coast. Shelf Sci., 2004, 59, 599-613.

41. Jayaraj, K. A., Sheeba, P., Jacob, J., Revichandran, C., Arun, P. K., Praseeda, K. S. and Rasheed, K. A., Response of infaunal macrobenthos to the sediment granulometry in a tropical continental margin-southwest coast of India. Estuarine Coast. Shelf Sci., 2008, 77(4), 743-754.

42. Sivadas, S. K., Ingole, B. S. and Fernandes, C. E. G., Environmental gradient favours functionally diverse macrobenthic community in a placer rich tropical bay. Sci. World J., 2013, 12, Doi: 10.1155/2013/750580.

43. Muniz, P. and Pires, A. M., Polycheate association in subtropical environment (Sao Sebastio Chanel Brezil): a structural analysis. Mar. Ecol., 2010, 21(2), 145-160.

44. Dolbeth, M., Cardoso, P. G., Ferreira, S. M., Verdelhos, T., Raffaelli, D. and Pardal, M. A., Anthropogenic and natural disturbance effects on a macrobenthic estuarine community over a 10 year period. Mar. Pollut. Bull., 2007, 54(5), 576-585.

45. Middelburg, J. J., Nieuwenhuize, J. and Van Breugel, P., Black carbon in marine sediments. Mar. Chem., 1999, 65, 245-252.

46. Khan, S. A., Murugesan, P., Lyla, P. S. and Jaganathan, S., A new indicator macro invertebrate of pollution and utility of graphical tools and diversity indices in pollution monitoring studies. Curr. Sci., 2004, 87, 1508-1510.

47. Rehitha, T. V., Ullas, N., Vineetha, G., Benny, P. Y., Madhu, N. V. and Revichandran, C., Impact of maintenance dredging on macrobenthic community structure of a tropical estuary. Ocean Coast. Manage., 2017, 144, 71-82.

48. Cruz-Motta, J. J. and Collins, J., Impacts of dredged material disposal on a tropical soft-bottom benthic assemblage. Mar. Pollut. Bull., 2004, 48, 270-280.

49. Snelgrove, P. V. R. and Butman, C. A., Animal-sediment relationships revisited: cause versus effect. Oceanogr. Mar. Biol. - An Аnnu. Rev., 1994, 32, 111-177.

ACKNOWLEDGEMENTS. We are grateful to the Director, CSIRNational Institute of Oceanography, Goa for support and encouragement. This work was carried out as a part of the Ballast Water Management Programme, India, funded by the Directorate General of Shipping, Government of India. This is a NIO contribution 6524.

Received 16 January 2020; revised 25 March 2020

doi: $10.18520 / \mathrm{cs} / \mathrm{v} 119 / \mathrm{i} 1 / 68-82$ 